\title{
ANTROPOLOGIA ESPECULATIVA DE LEÃO HEBREU
}

Sarah dos Santos ${ }^{1}$

Resumo: Este artigo analisa a importância do homem na obra renascentista Diálogos de amor de Leão Hebreu, onde o humano é apresentado como microcosmo do universo, contendo em pequena escala tudo o que o universo contém. Observaremos o amor como princípio de união, existente nos mundos inteligível, celeste e sublunar. A criação é exposta como uma recíproca relação de amor entre si e com Deus. Através do humano podemos compreender o amor em sua universalidade, pois participa de todos os mundos, sendo espelho universo e colaborador na unificação do Todo.

Palavras-chave: Filosofia, Filosofia Judaica, Renascimento, Neoplatonismo, Humano, Universo.

Abstract: this article analyzes the importance of mankind in the Renaissance work Dialogues of Loveby Lion Hebrew, where the human is presented as a microcosm of universe, containing in small scale all that the universe contains. Can we observe the principle of love as union existing in intelligible, celestial and sublunar worlds. Creation is exposed as a reciprocal relationship of love with each other and with God.Through the human, one can understand love in its universality, since it is part of all worlds, being mirror of the universe and collaborator in the unification of the whole.

Keywords: Philosophy, Jewish Philosophy, Renaissance, Neoplatonism, Human, Universe

\section{Introdução}

Leão Hebreu (YehudaAbravanel) foi um médico e filósofo neoplatônico do século XV. Nascido em Lisboa, Portugal, em uma família judaica nobre e influente, seu pai,

\footnotetext{
${ }^{1}$ Universidade Federal de São Paulo, Projeto de Iniciação científica, sarah.kadoshim@yahoo.com.br
} 
Isaac Abravanel, foi um célebre rabino, e, assim, Leão Hebreu era versado nas Sagradas Escrituras e no Talmud e tinha grande domínio da filosofia judaica e árabe. Nos Diálogos de Amor vemos a tentativa de compatibilização do judaísmo com a filosofia de Platão e Aristóteles, apresentada através do amor como princípio de união, conforme Empédocles.

A obra fala também sobre o decorrente aperfeiçoamento do universo e de seus respectivos seres. O humano é apresentado como microcosmo, contendo em pequena escala tudo o que o universo contém e também como colaborador no aperfeiçoamento do Todo. Em consonância com $O$ banquete de Platão, Leão Hebreu expõe o amor caracterizado pela privação. Porém, com a diferença de que esta privação pode ocorrer tanto no amado, menos perfeito, ao qual o amante deseja conferir sua perfeição, como também no amante - no qual falta a coisa amada. O amor tem dimensão vertical, pois abarca os mundos sublunar, celeste e inteligível, e horizontal, porque existe em todos os geráveis: nos quatro elementos e nos seres por eles compostos (minerais, vegetais, animais e humanos). É possível compreender o amor em sua universalidade através do humano, pois este é síntese do universo, e disso resulta que o humano é capaz de conhecer o universo conhecendo a si mesmo.

Leão Hebreu expõe o amor humano compreendendo três modos de amor sublunares (correspondentes ao mundo da matéria sensível e corruptível): natural, sensitivo e racional voluntário. Também apresenta as cinco causas de amor encontradas em todos os geráveis e acrescenta duas causas adicionais não encontradas nos seres sensitivos nem nos naturais, mostrando o quão exclusivas são no humano, as virtudes morais e conformidade de natureza. Leão faz correspondências entre a constituição física do humano e de suas capacidades superiores (como intelecção, por exemplo) com os mundos sublunar, celeste e inteligível, e suas respectivas constituições. Por participar de todos os mundos, o humano é capaz de colaborar no aperfeiçoamento do universo, pois a perfeição é proporcional e decorrente do grau de amor (união) entre os elementos e seres. Consequentemente, colabora também com a recondução do universo à sua Fonte.

No segundo livro, Sobre a universalidade do amor, é analisada a manifestação do amor no mundo sublunar, em todos os seus níveis de existência, e compreendemos como o humano abarca todos estes modos de amor. A matéria primeira - que 
corresponde ao Caos dos poetas antigos - é exposta como pura potência, indefinida e sem forma, sendo matéria comum dos quatro elementos, terra, água, ar e fogo, e a mistura destes compõe todos os seres sublunares. Os seres sublunares são compostos pelos elementos e têm o amor como princípio gerativo, que os unifica e os uniformiza, e o ódio como princípio de dissolução, em acordo com o pensamento de Empédocles. Ou seja, a perfeição e conformidade dos seres são proporcionais ao grau de amor.

Leão Hebreu exibe de maneira hierárquica a constituição dos seres corruptíveis em crescente grau de perfeição, em proporção com o grau de amor, indo dos naturais aos sensíveis, até alcançar o modo superior de constituição entre os corruptíveis. O amor dos naturais insensíveis, como são os elementos, os metais ou minerais, decorre da alma do mundo, fazendo-os buscar cada um o seu lugar natural. Os seres sensíveis possuem tal amor natural, porém têm um nível superior, pois têm o sentir, o movimento e o apetite, que propiciam a busca daquilo que amam ou a fuga do que odeiam. $\mathrm{O}$ amor sensitivo está presente nos animais irracionais e nos homens, sendo mais perfeito que o natural, contudo menos perfeito que o amor racional voluntário. $\mathrm{O}$ amor racional voluntário constitui o último grau de amor no mundo da geração e corrupção, somente o homem o possui, entre os seres sublunares, de modo que é capaz da forma de amor mais perfeita do mundo inferior.

O humano abarca todos os níveis de amor do mundo inferior e contém as cinco causas de amor presentes nos seres sublunares: desejo e deleite, sucessão generativa, benefício, instinto natural da mesma espécie e amor dado à companhia. Além destas causas, o humano contém mais duas: as virtudes morais e intelectuais e compleição de natureza.

O desejo e deleite fazem o homem e a mulher se procurarem, como ocorre com os irracionais entre macho e fêmea e com os insensíveis naturais, como o deleite da matéria primeira pelas formas geradas. $\mathrm{O}$ amor causado pela sucessão generativa, no homem, é o dos pais pelos filhos; entre animais irracionais, dos genitores pelas crias; e, entre os naturais, da matéria primeira por seus elementos. Já o amor causado pelo benefício se dá entre o benfeitor e beneficiado, como entre mestre e discípulo. $\mathrm{O}$ amor do benefício pode ser observado entre os irracionais, quando um animal cuida de outro, e, entre os naturais insensíveis, identifica-se com a sucessão generativa. 
"o gerado ama o generante como seu benfeitor e o generante ama o gerado como receptor do benefício" 2

O amor pelo instinto natural da mesma espécie ocorre quando o humano ama seus semelhantes - entre os que compartilham a mesma espécie ou pátria. Tal amor é visto entre os animais da mesma espécie, e nos insensíveis, ocorre quando cada coisa procura seu lugar natural, junto a seus semelhantes. $\mathrm{O}$ amor decorrente da continuidade da companhia é o que permite que inimigos passem a se amar com o decorrer do tempo. Nota-se esse tipo entre racionais e irracionais, e nos naturais é visto, por exemplo, quando o ar procura a companhia do fogo. Este amor é mais acentuado no humano, por causa da linguagem, tornando a relação mais intensa entre as pessoas.

O homem contém em si todos os tipos inferiores de amor e causas de amor sublunares, como está exposto: “com o amor mais excelente encontram-se os menos excelentes, mas com aquele que é menos nem sempre se encontra o que é mais" ${ }^{3}$.

As duas últimas causas de amor, exclusivas no humano entre os sublunares são: conformidade de natureza, que depende da posição dos astros no momento do nascimento das pessoas, provocando amor ou ódio imediatamente entre humanos. Em Leão Hebreu, a causa astrológica tem relação com sua cosmologia, pois o mundo sublunar procede e recebe formas do mundo celeste; e o celeste, do inteligível. O amor causado pelas virtudes morais e intelectuais é promovido pela razão, tornando o humano mais excelente e virtuoso.

Através do humano compreendemos o amor em sua dimensão horizontal, em todos os níveis de existência corruptíveis. Leão Hebreu apresenta a correspondência do corpo humano (em sua parcela inferior) com o mundo sublunar. Apresenta o corpo em três partes, sendo a parcela do pé até o diafragma simulacro do mundo inferior, pois esta parte humana contém membros e órgãos de geração, nutrição e excreção, semelhante à geração e corrupção da Terra.

Além dessa semelhança, há também a de que nesta secção do corpo humano são produzidos os quatro humores (bile, bile negra, sangue e água) a partir do alimento, em

2 HEBREU, Leão.Diálogos de amor:Sobre a universalidade do amor.Lisboa: Imprensa Nacional Casa da moeda, 2001 pág.127.

3 HEBREU, Leão.Diálogos de amor: Sobre a universalidade do amor.Lisboa: Imprensa Nacional Casa Moeda, 2001, pág.121. 
correspondência com a geração e corrupção dos quatro elementos a partir da matéria primeira.

O amor não é apenas horizontal e exclusivo do mundo sublunar, pelo contrário, ele se encontra em maior grau nos mundos superiores, no celeste e no inteligível. Pode ser compreendida a correspondência do humano com o mundo celeste, a partir da interpretação de Leão Hebreu do discurso de Aristófanes em O banquete. Aristófanes expõe na obra platônica o mito do andrógino perfeito, uma terceira raça composta de metade homem e metade mulher. Leão compreende a partir do mito que o humano seja composto de um princípio feminino, de caráter passivo, e outro masculino, de caráter ativo. A parcela masculina são as virtudes morais e intelectuais, doadoras de forma ao corpo, sendo simulacro do mundo celeste, doador de formas à matéria primeira.

O filósofo compatibiliza o mito do andrógino com as Sagradas escrituras:

“Por isso, não só na língua latina 'homem' indica macho e fêmea, mas também na língua hebraica, mãe antiquíssima e origem de todas as línguas 'Adão', que quer dizer 'homem' significa macho e fêmea'” 4 .

Em outro tipo de correspondência, Leão expõe o ato copulativo entre homem e mulher semelhante ao dos Céus e a Terra. Em seus movimentos sobre a Terra, os Céus atualizam as potencialidades infinitas da matéria primeira, fazendo emergir do caos os seres e elementos, semelhantemente o homem, que é princípio ativo, com seus movimentos instila formas através do sêmen na mulher, principio passivo.

Além desta semelhança, o filósofo faz outras correspondências do mundo celeste como corpo humano, por causa da semelhança de suas qualidades. Relaciona os planetas com os órgãos generativos e cognitivos: o coração e o olho direito são simulacros do sol; o cérebro e o olho esquerdo correspondem à lua; o fígado e ouvido correspondem a Júpiter; o baço e outro ouvido correspondem a Saturno; os rins e uma das fossas nasais correspondem a Marte; os testículos e a outra fossa nasal correspondem a Vênus; o pênis e a língua correspondem a Mercúrio.

Em continuidade com o modo inicial de correspondência - do corpo seccionado em três partes - a parte intermediária, do diafragma à cabeça, é simulacro do mundo 
celeste, pois esta parcela contém os órgãos espirituais. O coração seria o motor do movimento dos outros órgãos, correspondendo à oitava esfera promovedora do movimento dos planetas erráticos.

No decorrer do texto, as capacidades superiores humanas são apresentadas como participantes do mundo inteligível, e no corpo correspondem à cabeça. Estas capacidades são divididas em três graus: a alma, intelecto possível e intelecto agente (divindade). Em acordo com a filosofia neoplatônica de sua época, o filósofo concebe que a alma do mundo procede do mundo espiritual (inteligível) e que igualmente atua animando o mundo sensível, o celeste e o sublunar. Ou seja, a alma do mundo - e sua refração, a alma individual - é de natureza mista, pois participa do corpóreo e do espiritual.

No humano, a alma anima o corpo, produz o movimento e o sentir, sustenta a vida, auxilia os processos de nutrição e de restauração do organismo, e também atua nos processos intelectuais e contemplativos. Esse caráter não homogêneo é exposto em seu terceiro livro Sobre a origem do amor:

"Pois quando a mente espiritual [...] por força do desejo se recolhe em si própria a contemplar num íntimo e almejado objecto, chama para si a alma toda [...] deixando os olhos sem vista, os ouvidos sem ouvir e assim os outros órgãos” ${ }^{5}$.

$\mathrm{O}$ entendimento decorrente dos sentidos compreende as coisas que estão em constante mutação, sob geração e corrupção, que apresentam contrariedades, caracterizando deste modo uma compreensão imperfeita. Diferentemente ocorre com o intelecto possível no homem, quando é atualizado, porque obtém um entendimento não relativo das coisas. Conhece num único remate, de modo simples e uno, os níveis do universo e suas formas não em potência ou em vir-a-ser, mas em ato.

O intelecto agente, por sua vez, é caracterizado por Leão sendo o Próprio Deus, que atualiza esta capacidade que todo humano possui, permitindo a união do humano com o Divino.

5 HEBREU, Leão. Diálogos de amor: Sobre a origem do amor. Lisboa: Imprensa Nacional Casa Moeda, 2001, pág.220 -221. 
A concepção do homem como síntese e espelho do universo, analisada nas correspondências do humano com os três mundos, segue a cosmologia neoplatônica corrente em seu período. Os filósofos da época atribuíam a Aristóteles os escritos de outros filósofos, como os de Proclo, por exemplo. Seguindo esse modo de leitura, e compatibilizando a filosofia com a sua religião, Leão Hebreu associa Deus ao Uno neoplatônico. Do Uno procede o Nous - mundo inteligível, das inteligências puras ou formas puras - do qual procede a Alma do mundo, que anima o universo; por fim, desta procede a natureza, compondo o mundo material, o celeste e o mundo sublunar.

Em todos os níveis de existência é encontrado o amor, e a relação de amor entre amante e amado não é apenas o amor do inferior ao superior, é também o do superior ao inferior. Leão Hebreu segue a concepção platônica de amor, descrita em O Banquete, pois o amor é caracterizado pela privação, como é observado no discurso de Sócrates, sobre o nascimento de Eros, ser mediano e amante de Afrodite.

Em Platão, o amor é encontrado tão somente no amante, que é privado da perfeição do amado, superior a ele. Contudo, diferente de Platão, Leão amplia o conceito de amor, e apresenta o amor existente também no ser superior para com o inferior, o amor dos inteligíveis pelos celestes, e dos Céus pela Terra. A ideia de amor como privação de perfeição é mantida; no entanto, quando um superior ama o inferior não é para suprir sua própria carência, mas sim para suprir a carência do inferior, o beneficiando. Deus, que é de suma perfeição, ama sua criação e deseja que ela una-se a Ele para que seja rematada sua perfeição. Com mais perfeito amor o superior ama o inferior:

“[...] aquele o deseja a perfeição do inferior e uni-lo a si para o livrar do defeito, porque, libertando-o, salva-se a si próprio da falta e da imperfeição”6

De acordo com o texto, a imperfeição do efeito provém da sua causa, e, ao livrar seu efeito da imperfeição, a causa livra a si mesma da imperfeição. Deste modo os inteligíveis amam os celestes e desejam uni-los a si para apartá-los da imperfeição e, consequentemente, da própria imperfeição. Da mesma maneira os celestes amam os sublunares.

6 HEBREU, Leão. Diálogos de amor: Sobre a universalidade do amor. Lisboa: Imprensa Nacional Casa Moeda, 2001, pág.202. 
Na união dos respectivos amantes e amados se arremata a perfeição de cada um, tendo o amor como princípio: "na ordem do Universo, o inferior depende do superior e o mundo corpóreo do espiritual: por conseguinte a deficiência do inferior acarretaria a deficiência do superior de que depende" 7

Ao observar sua constituição e funcionamento de suas capacidades, o humano enxerga o universo como num espelho, vendo em si todos os graus de existência, desde o modo mais grosseiro, em seu corpo (matéria), até os modos mais sutis, como intelecto. É compreendido que toda a sua constituição heterogênea é harmonizada e unificada pelo amor, como acontece com o universo como um todo que Leão chamará de grande animal. Portanto, é no humano que vemos o universo em menor escala.

O humano, nos Diálogos, é concebido como colaborador na unificação dos mundos, pois ele é o único ser que contém em si, em menor grau, todos os níveis do universo. É amando que atua como colaborador, pois o amor é princípio unitivo de todas as coisas e seres, observado desde os elementos até os seres inteligíveis. Constituído de alma intelectiva e simultaneamente composto de matéria, o humano traz luz e vida dos mundos superiores ao mundo material e inferior.

Somente com a colaboração na unificação dos mundos o homem realiza seu fim. Abravanel apresenta a beatitude humana como o remate da sua perfeição, ocorrida com a atualização do intelecto possível, na união com o Divino. Portanto, o fim último do humano não é em si mesmo ou simplesmente ter uma vida virtuosa. Consuma sua finalidade com o trabalho de unificação e com a atualização do seu intelecto. 